\title{
Analysis of the Proximate Composition, Anti-Nutrients and Mineral Content of Maerua Crassifolia Leaves
}

\author{
*1U.I. Aletan and 2 H.A. Kwazo \\ ${ }^{1}$ Department of Pure and Applied Sciences, Faculty of Science, National Open University of Nigeria, Abuja. Nigeria \\ 2Department of Chemistry, Shehu Shagari College of Education, Sokoto, Nigeria \\ [Corresponding Author: E-mail: ualetan@noun.edu.ng; ?:234 8070707683]
}

\section{ABSTRACT}

This study was carried out to determine the proximate composition, anti-nutrient and the mineral content of Maerua crassifolia leaves. Proximate analysis was performed using standard AOAC methods, mineral contents were determined using atomic absorption spectrometry while the anti-nutrients were analysed using standard methods. The results revealed that the leaves had moisture content of $62.00 \%$, ash content of $12.17 \pm 0.47 \mathrm{~g} / 100 \mathrm{~g}$ and crude protein content of $15.17 \pm 0.02 \mathrm{~g} / 100 \mathrm{~g}$. The value of the minerals ranged between $75.33 \pm 0.05 \mathrm{mg} / \mathrm{kg}$ for potassium and $2.88 \mathrm{mg} / \mathrm{kg}$ for magnesium. For the heavy metals, zinc had the highest value of $0.22 \pm 0.02 \mu \mathrm{g} / \mathrm{mg}$. The sodium: potassium ratio was calculated to be 0.92 \pm 0.00 . All the anti-nutrients studied were below the lethal doses recommended. The results obtained indicate that the leaf will be a good source of nourishment if properly utilized.

Keywords: proximate composition, mineral content, anti-nutrients, Maerua crassifolia

\section{INTRODUCTION}

In most developing nations like Nigeria, numerous types of edible wild plants are used as sources of food (Aberoumand, 2010). Edible wild plants are sources of medicines, food, shelters and other items used by humans every day. Their roots, stems, leaves, flowers, fruits and seeds provide food for humans (Edem and Miranda, 2011). Edible wild plants and their products have played a role in bridging the ever increasing gap between population vital statistics and provender (Bhat et al., 2010; Patel and Naik, 2010). However, to reduce the effect of food scarcity, more attention has to be given to the exploitation and utilization of unusual edible wild plants especially edible leaves which can be a source of nutrient to the general populace. The Maerua crassifolia tree is such a plant. The $M$. crassifolia plant belongs to the family of Caparaceae. They are permanent green trees; their branches are twisted and often densely leaved as represented in Figure 1. The leaves are variable in shape and size, $5-15 \mathrm{~mm}$ long and $2-8 \mathrm{~mm}$ broad, rather fleshy, smooth and almost sessile, flowers are white, sweet-scented and without petals. Fruits are pubescent irregular cylindrical pods, $3-6 \mathrm{~cm}$ long, $0.6-1 \mathrm{~cm}$ broad, distinctly constricted into 1-6 sections (Patel and Naik, 2010; Jstor, 2010).

The tree considered multipurpose is used as food for goats and wood for house furniture. The leaves which are edible to humans also serve as animal food and have many medical benefits as treatment for fever, stomach troubles and skin diseases (Saad and Asalam, 2015). The leaves of this plant have long been used for the treatment of malaria (Akuodor et al., 2014) gastric ulcer, toothache and intestinal diseases (Rahman et al., 2004).

In Nigeria, the plant is mainly found in Sokoto and some parts of Zamfara and Katsina states (North West Nigeria). The plant is called 'Jiga' in Sokoto in Nigeria, 'Agargar' in Republic of Niger (Rahman et al., 2004). There were several claims which suggest that most edible leaves of wild plants are collected and consumed locally in different areas during the blooming season (Horo and Topno, 2015; Geng et al., 2016) Unfortunately, there is a dearth of information on the nutritive value of this leaf. This study, consequently aims at determining the proximate 
composition and some elements as well as some anti- nutrients in M. crassifolia leaf to ascertain the nutritive value of the leaves.

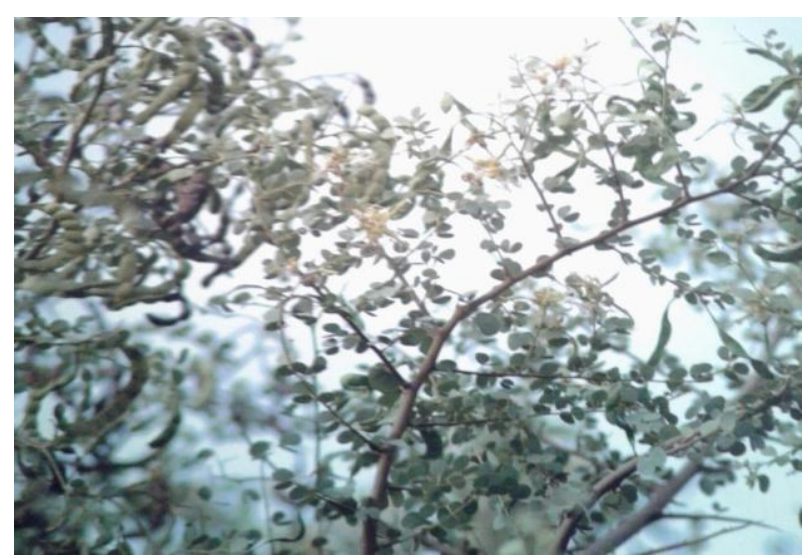

Figure 1: Picture of the Maerua crassifolia plant showing the leaves and fruit

\section{MATERIALS AND METHOD Sample Collection}

The sample of the leaves was obtained from trees in various locations in Shagari Local Government of Sokoto State and was identified at the Botany Unit of the Department of Biological Science, Faculty of Science, Usmanu Danfodiyo University Sokoto, Nigeria, with voucher identification number UDUH/ANS/0210.

\section{Sample Treatment}

The fresh leaves were separated manually, washed carefully with distilled water and dried under a shade. The leaves for determining moisture content were however separated from the lot before the drying procedure. The dried sample was ground into fine powder using an electric blender and sifted using sieve $2.0 \mathrm{~mm}$ mesh. The analyte was stored in air tight polythene for subsequent analysis. The dried powdered sample was used for the analysis, except determination of moisture content where a fresh sample was used. All determinations were carried out in triplicates unless otherwise stated.

\section{Proximate Analysis}

Proximate analysis was carried out according to the procedure of Association of Official Analytical
Chemist (A.O.A.C., 1990) for moisture, ash, crude fibre and crude protein content. The carbohydrate was calculated by difference method (A.O.A.C., 1990) by subtracting the sum (g/100g dry matter) of crude protein, crude fat, ash and fibre from $100 \mathrm{~g}$. The caloric value was determined based on the Atwater factor (FAO, 2003).

\section{Mineral Analysis Sample Digestion}

The digestion method described by Sahrawat et al. (2002) was adopted for the sample digestion.

\section{Analysis of metal using AAS}

Elemental analysis with the exception of sodium, potassium and phosphorous was carried out by Atomic Absorption Spectrometry (AAS). Sodium and potassium were measured using flame photometer while phosphorus was determined by vanadomolybdate colorimeteric method (Ologhobo and Fetuga, 1983).

\section{Analysis of Anti-nutritional Factors Determination of Total Phytate}

The method of Ola and Oboh (2000) was adapted for the determination of phytate.

\section{Determination of Total Oxalate}

The method of Krishna and Ranjhan (1980) was adopted for the determination of total oxalate.

\section{Determination of Hydrocyanic Acid}

The method of AOAC (1990) was adopted for this analysis.

\section{Statistical analysis}

Except in the case of moisture content where percentage was involved and heavy metals which were not detected (ND), data collected for each parameter were analyzed for their central tendencies (mean) using descriptive statistics; values were expressed as mean \pm standard deviation of the observations. 


\section{Nigerian Journal of Basic and Applied Science (June, 2019), 27(1): 89-96}

\section{RESULTS}

Table 1 represents the result of the proximate composition of M. crassifolia leaves. The leaves showed $62 \%$ moisture content. Ash content was $12.17 \pm 0.47 \mathrm{~g} / 100 \mathrm{~g}$. Crude lipids content of $3.17 \pm 0.47 \mathrm{~g} / 100 \mathrm{~g}$, Crude fat content of $4.67 \pm$ $0.23 \mathrm{~g} / 100 \mathrm{~g}$. Crude protein and carbohydrate were $15.17 \pm 0.02 \mathrm{~g} / 100 \mathrm{~g}$ and $64.83 \pm 0.36$ $\mathrm{g} / 100 \mathrm{~g}$ respectively. The leaves showed a caloric value of $348.29 \pm 6.11 \mathrm{kcal} / 100 \mathrm{~g}$.

Table 1: Proximate composition of Maerua crassifolia leaves

\begin{tabular}{ll}
\hline Parameters & Composition \\
\hline Moisture $(\%)$ & 62.00 \\
Ash content $(\mathrm{g} / 100 \mathrm{~g})$ & $12.17 \pm 0.47$ \\
Crude lipids $(\mathrm{g} / 100 \mathrm{~g})$ & $3.17 \pm 0.47$ \\
Crude fibre $(\mathrm{g} / 100 \mathrm{~g})$ & $4.67 \pm 0.23$ \\
Crude protein $(\mathrm{g} / 100 \mathrm{~g})$ & $15.17 \pm 0.02$ \\
Carbohydrate $(\mathrm{g} / 100 \mathrm{~g})$ & $64.83 \pm 0.36$ \\
Caloric value $(\mathrm{kcal} / \mathrm{g})$ & $348.29 \pm 6.11$ \\
\hline
\end{tabular}

All values except for moisture are expressed in dry weight All values represent mean \pm standard deviation of triplicate determinations

Table 2 represents the mineral content of $M$. crassifolia leaves in $\mathrm{mg} / \mathrm{kg}$. Sodium was $69.17 \pm$ $0.10 \mathrm{mg} / \mathrm{kg}$, potassium $(75.33 \pm 0.05 \mathrm{mg} / \mathrm{kg})$, calcium was $3.05 \pm 0.10 \mathrm{mg} / \mathrm{kg}$ while magnesium and phosphorus were $2.88 \pm 0.02$ and $4.34 \pm$ 0.02 respectively. sodium: potassium $(\mathrm{Na} / \mathrm{K})$ was $0.92 \pm 0.00$ while calcium: phosphorus $(\mathrm{Ca} / \mathrm{P})$ was $0.70 \pm 0.00$.

Table 2: The mineral content of Maerua crassifolia leaves

\begin{tabular}{ll}
\hline Element & $\begin{array}{l}\text { Concentration } \\
(\mathrm{mg} / \mathrm{kg})\end{array}$ \\
\hline Sodium $(\mathrm{Na})$ & $69.17 \pm 0.10$ \\
Potassium $(\mathrm{K})$ & $75.33 \pm 0.05$ \\
Calcium $(\mathrm{Ca})$ & $3.05 \pm 0.10$ \\
Magnesium $(\mathrm{Mg})$ & $2.88 \pm 0.02$ \\
Phosphorus $(\mathrm{P})$ & $4.34 \pm 0.02$ \\
Na/K & $0.92 \pm 0.00$ \\
$\mathrm{Ca} / \mathrm{P}$ & $0.70 \pm 0.00$ \\
\hline
\end{tabular}

Data are mean of triplicate results \pm standard deviation of triplicate determinations
Table 3 represents the heavy metal contents of the $M$. crassifolia. The selenium content was 0.18 $0.18 \pm 0.02 \mu \mathrm{g} / \mathrm{mg}$, cadmium was $0.05 \pm 0.00$ $\mu \mathrm{g} / \mathrm{mg}$. Zinc and copper had levels of $0.18 \pm 0.01$ $\mu \mathrm{g} / \mathrm{mg}$ and $0.22 \pm 0.02 \mu \mathrm{g} / \mathrm{mg}$ respectively. Manganese, nickel, chromium and lead were not detected (ND).

Table 3: Heavy metal contents of Maerua crassifolia leaves

\begin{tabular}{ll}
\hline Element & $\begin{array}{l}\text { Concentration } \\
(\mu \mathrm{g} / \mathrm{mg})\end{array}$ \\
\hline Selenium & $0.18 \pm 0.02$ \\
Cadmium & $0.05 \pm 0.00$ \\
Manganese & $\mathrm{ND}$ \\
Nickel & $\mathrm{ND}$ \\
Chromium & $\mathrm{ND}$ \\
Copper & $0.18 \pm 0.01$ \\
Lead & $\mathrm{ND}$ \\
Zinc & $0.22 \pm 0.02$ \\
\hline
\end{tabular}

Data are mean of triplicate results \pm standard deviation of triplicate determinations

Table 4 represents the anti-nutritional composition of $M$. crassifolia leaves. The level of the oxalate was 0.01

Table 4:Anti-nutritional composition of Maerua crassifolia leaves

\begin{tabular}{ll}
\hline Component & $\begin{array}{l}\text { Composition } \\
(\mathrm{mg} / 100 \mathrm{~g})\end{array}$ \\
\hline Oxalate & $0.01 \pm 0.00$ \\
Phytate & $2.31 \pm 0.01$ \\
Cyanide & $0.20 \pm 0.00$ \\
\hline
\end{tabular}

Data are mean of triplicate results \pm standard deviation of triplicate determinations

\section{DISCUSSION}

The result of proximate composition of Maerua crassifolia leaves revealed that the sample had an average moisture content of $62.00 \%$. This is not too much compared to moisture content of leaves like Corchorus oiltorius leaves-79.98 \% (Adeniyi et al., 2012) and Moringa oleifera leaves- $76.53 \%$ (Owusu, et al., 2008). As reported by Emebu and Anyika (2011), micro- 
organisms that encourage food spoilage flourish well in foods with high moisture contents, thereby reducing the shelf life. However, lowering the moisture content could give a longer shelf life and also ease of transportation of $M$. crassifolia leaves.

The ash content of $12.17 \pm 0.47 \mathrm{~g} / 100 \mathrm{~g}$ recorded for the $M$. crassifolia leaves is high in comparison to $1.6 \mathrm{~g} / 100$ gand $1.5 \mathrm{~g} / 100 \mathrm{~g}$ respectively for Talinum triangulare and fresh Telferia occidentalis (Orhuamen, et al., 2012) and $2.5 \mathrm{~g} / 100 \mathrm{~g}$ and $2.4 \mathrm{~g} / 100 \mathrm{~g}$ Vernonia amygdalina and Moringa oleifera respectively (Saidu and Jideobi, 2009). According to Fagbohun et al. (2012), ash content in leafy vegetables is a reflection of the amount of mineral elements present in the vegetables. High ash content in a leafy vegetable would suggest high mineral content, therefore improved the nutritional quality (Ifon and Bassir, 1980). However, this may not always be the case according to Ukam (2008) who noted that it could be the reverse if it contained toxic metals which also contribute to the percentage ash content. Fortunately, the heavy (toxic) metal level in $M$. crassifolia as seen in Table 3 is low.

Maerua crassifolia leaf is low in crude fat with a value of $3.17 \pm 0.47 \mathrm{~g} / 100 \mathrm{~g}$ compared to reported values (8.3-27 g/100 g) in some vegetables consumed in West Africa (Akubugwo et al., 2007). The crude fibre content is relatively low in Maerua crassifolia leaves, $4.67 \pm 0.23$ $\mathrm{g} / 100 \mathrm{~g}$, compared to Gnetum africanum, 37.80 g/100 g, (Ndomou et al., 2014). Unlike some leaves that require the softening properties of other leaves to make them palatable (Nkongho et al., 2014), the Maerua crassifolia leaves will not require the softening properties of other leaves to make them palatable.

The average crude protein content of $M$. crassifolia leaves obtained from the analysis was $15.17 \pm 0.02 \mathrm{~g} / 100 \mathrm{~g}$. In comparison to cowpea (Vigna unguiculata) $19.82 \mathrm{~g} / 100 \mathrm{~g}$ (Famata et al., 2013) which is normally considered a source of plant protein this value is not too low. Plant protein still remains a main source of food nutrient for the less privileged population in developing countries, Nigeria inclusive (Emebu and Anyika, 2011). The protein content of the $M$. crassifolia leaves makes it fit to be considered as a good plant protein supplement.

The available carbohydrates content of $M$. crassifolia leaves found to be $64.83 \pm 0.36 \mathrm{~g} / 100$ $\mathrm{g}$ is high when compared to dried Moringa leaves $45.3 \mathrm{~g} / 100 \mathrm{~g}$ (Ogbe and Affiku, 2011) ,43.8 g/100 $\mathrm{g}$ (Anthonia, 2002) 63.11 g/100 g (Onu and Aneibo, 2011) and Piper guinenses $48.21 \pm 0.00$ $\mathrm{g} / 100 \mathrm{~g}$, Ocimum gratissium $40.30 \pm 0.04 \mathrm{~g} / 100$ $\mathrm{g}$ (Nwankwo et al.,2014). Since M. crassifolia leaves has high carbohydrates content, its consumption could provide the body with fuel and energy that is required for daily activities and exercise (Udousoro and Ekanem, 2013). Adequate carbohydrate is also required for optimum function of the brain, heart, nervous, digestive and immune system while carbohydrate deficiency causes depletion of body tissue (Offor et al., 2014). The calorific value of the $M$. crassifolia leaves determined by calculation was $348.64 \pm 6.11 \mathrm{kcal} / 100 \mathrm{~g}$. This is in agreement with results of Antia et al. (2006) who recorded values between 248.8-307.1 $\mathrm{kcal} / \mathrm{g}$ for some Nigerian leafy vegetables. Therefore, affirming the universal observation that vegetables have low energy value (Lintas, 1992) due to their low lipid content and relatively high moisture in comparison to their other components. Minerals are inorganic substances, present in all body tissues and fluids. Their presence is required to maintain certain physical and chemical processes which are essential to life (Anavi, 2013). The concentrations of different mineral elements in $M$. crassifolia leaves analysed are reported in Table 2 .Iron was not detected. The ratio of sodium to potassium $(\mathrm{Na} / \mathrm{K})$ and calcium to phosphorus $(\mathrm{Ca} / \mathrm{P})$ are shown on the same table. The sodium/potassium $(\mathrm{Na} / \mathrm{K})$ ratio for $M$. crassifolia leaves is $0.92 \pm 0.001$. This value according to The BMJ (2015) makes for a desirable dietary sodium-potassium ratio of 


\section{Nigerian Journal of Basic and Applied Science (June, 2019), 27(1): 89-96}

approximately 1.0. High sodium /potassium ratio has been implicated in cardiovascular disease (Anavi, 2013).

The Calcium: Phosphorus (C: P) ratio recorded for M. crassifolia is $0.70 \pm 0.001$. This falls below the optimum ratio of $1: 1$ (McDowell, 2003) that is being advocated. According to Pravina et al. (2013), calcium deficiency can lead to osteoporosis in which the bone deteriorates and there is an increased risk of fractures. If there is more phosphorus than calcium in the diet, the body will start to take calcium from its own reserves (the bones) to compensate. Over a long or short period of time, this may affect the bones in a negative way. It is therefore necessary that a good source of calcium is used to complement the M. crassifolia leaves in diet.

The $M$. crassifolia leaves have a very minute quantity of zinc, copper, cadmium, and selenium as $0.22 \pm 0.02,0.18 \pm 0.01,0.05 \pm 0.001$ and $0.18 \pm 0.02$ all in $\mu \mathrm{g} / \mathrm{mg}$ respectively. Meanwhile manganese, nickel, chromium and lead were not detected. Thus consumption of the leaves will not pose a threat of heavy metal ingestion.

Oxalate is an anti-nutrient responsible for kidney stone, electrolyte imbalance and irritation of digestive system in man and animal (Egbuna, and Ifemeje, 2015) dried M. crassifolia leaves has oxalate $(0.01 \mathrm{~g} \pm 0.001 \mathrm{mg} / \mathrm{ml})$ which is quite low. Oxalates affect calcium and magnesium metabolism and react with proteins to form complexes which have an inhibitory effect in peptic digestion (Akande et al., 2010). Phytic acid $(2.31 \pm 0.01 \mathrm{mg} / \mathrm{ml})$ (inositol hexaphosphate) in plants binds calcium in the intestinal lumen, preventing its absorption as well as other minerals including zinc, are also chelated by phytate (Adesuyi et al., 2012). Cyanide in $M$. crassifolia $(0.197 \pm 0.001 \mathrm{mg} / \mathrm{ml})$ is considered to be non-toxic when ingested due to its very small amount. Thus, the results revealed that the antinutrient composition of $M$. crassifolia were generally low such that none of the anti-nutrients was above the lethal dosage approved by standard bodies like National Agency for Food and Drugs Administration and Control (NAFDAC) in Nigeria (Bolanle et al., 2014).

\section{CONCLUSION}

The proximate and mineral analysis of Maerua crassifolia leaves have shown that the leaf is worthy of being exploited outside its immediate locality. Having a protein content that is comparable with good sources of plant protein as well as low heavy metal and toxicant levels, a moisture content that makes the transportation outside the locality convenient due reduced bulkiness which consequently increased shelf life; Maerua crassifolia will make a good nutrient source for the ever growing population.

\section{REFERENCES}

Aberoumand, A. (2010): A comparative study of nutrients and mineral molar ratios of some plant foods with recommended dietary allowances, Advance Journal of Food Science and Technology, 2(2), 104-108

Adeniyi, S.A., Ehiagbonare, J.E.and Nwangwu, S., C., O. (2012): Nutritional evaluation of some staple leafy vegetables in Southern Nigeria International Journal of Agricultural and Food Science, 2(2): 3743.

Adesuyi, A. O., Awosanya, O. A., Adaramola, F. B., and Omeonu, A. I. (2012): Nutritional and Phytochemical Screening of "Aloe barbadensis". Current Research Journal of Biological Sciences, 4(1), 4-9

Akande, K. E., Doma, U. D., Agu, H. O., and Adamu, H. M. (2010): Major anti-nutrients found in plant protein sources: their effect on nutrition. Pakistan Journal of Nutrition, 9(8), 827-832

Akubugwo, I. E., Obasi, N. A., Chinyere, G. C., \& Ugbogu, A. E. (2007): Nutritional and chemical value of Amaranthus hybridus $L$. leaves from Afikpo, Nigeria. African Journal of Biotechnology, 6(24) 2833-2839

Akuodor, G. C., Ibrahim, J. A., Akpan, J. L., Okorie, A. U., and Ezeokpo, B. C. (2014): 
Phytochemical and anti-diarrhoeal properties of methanolic leaf extract of Maerua crassifolia Forssk. European Journal of Medicinal Plants, 4(10) 12231231

Anavi, S. (2013): Nutrition and Health-The Importance of Potassium. Switzerland: International Potash Institute; p. 3.

Oluduro,A.O. (2002): Evaluation of antimicrobial properties and nutritional potential of Moringa leaves in South-Western Nigeria. Malaysian Journal of Microbiology, 8(2): 59 - 67.

Antia, B.,S. , Akpan, E.,J., Okon, P.,A., and Umoren, I.,U.(2006) :Nutritive and antinutritive evaluation of sweet potatoes (Ipomoea batatas) leaves. Pakistan Journal Nutrition, 5: 166-168.

AOAC (1990): Official Methods of Analysis of the Association of Official's Analytical Chemists, 14th Ed. Association of Official Analytical Chemist, Washington D.C., pp: 223-225, 992-995.

Bhat, R., Kiran, K., Arun, A. B., and Karim, A. A. (2010): Determination of mineral composition and heavy metal content of some nutraceutically valued plant products. Food analytical methods, 3(3), 181-187.

Bolanle, A. O., Funmilola, A. S., and Adedayo, A. (2014): Proximate analysis, mineral contents, amino acid composition, antinutrients and phytochemical screening of Brachystegia eurycoma Harms and Pipper Guineense Schum and Thonn. American Journal of Food and Nutrition, 2(1), 11-17

Edem, C. A., and Miranda, I. D. (2011): Chemical evaluation of proximate composition, ascorbic acid and anti-nutrients content of African star apple (Chrysophyllum afrcanum) fruit. International Journal of Research Review and Applied Sciences, 9, 146-149.

Egbuna, C. and Ifemeje, J. C. (2015): Biological functions and anti-nutritional effects of phytochemicals in living system. Journal of Pharmacy and Biological Sciences, 10(2),
10-19.

Emebu, P. K., and Anyika, J. U. (2011): Vitamin and anti-nutrient composition of kale (Brassica oleracea) grown in Delta State, Nigeria. Pakistan Journal of Nutrition, 10(1), 76-79

FAO (2003): Food energy-methods of analysis and conversion factors. FAO Food and nutrition paper 77 .

Famata, A. S., Modu, S., Mida, H. M., Hajjagana, L., Shettima, A. Y., \& Hadiza, A. (2013). Chemical composition and mineral element content of two cowpea (Vigna unguiculata $L$. walp.) varieties as food supplement. International Research Journal of Biochemistry and Bioinformatics, 3(4), 93-96.

Fagbohun, E., D., Lawal, O., U. and Ore, M., E. (2012): The proximate, mineral and phytochemical analysis of the leaves of Ocimum grattissimum L., Melanthera scandens $\mathrm{A}$. and Leea guineensis $\mathrm{L}$. and their medicinal value International Journal of Applied Biology and Pharmaceutical Technology, 3: 15-22.

Geng, Y., Zhang, Y., Sailesh, R., Huai, H., and Wang, Y.(2016) Traditional knowledge and its transmission of wild edibles used by the Naxi in Baidi Village, northwest Yunnan province. Journal of Ethnobiology and Ethnomedicine 12: 1031

Horo. S., Topno, S.(2015): Study and analysis of nutritional value of some wild and semi wild edible plants consumed by "HO" tribes of W. Singhbhum district, Jharkhand, India. International Journal of Herbal Medicine, 3(5): 25-32.

Ifon, E., T. and Bassir, O. (1980): The nutritive value of some Nigerian leafy green vegetable: The distribution of protein, carbohydrate, crude fat, fibre and ash. Food Chemistry, 1: 231-235. .

JSTOR (2010). JSTOR Plant Science, https://www.en.wikipedia.org/wiki/JSTOR , Accessed March 12. 2017

Krishna, G. and Ranjhan, S. K. 


\section{Nigerian Journal of Basic and Applied Science (June, 2019), 27(1): 89-96}

(1980): Laboratory manual for nutrition research .Vikas Publishing House PVT

Limited, Ghaziabad, U.P. (India). Pp.104

Lintas C (1992): Nutritional aspects of fruits and vegetable consumption.nOptions

Meditérraneennes, 19: 79- 87.

McDowell, L., R (2003): Minerals in animal and human nutrition. 2nd Edn., Elsevier Science B.V. Amsterdam, The Netherland, pp: 644.

Ndomou, M., Mezajoug, $\mathrm{K}$ and Tchiegang, C.(2014) : Physico-chemical properties of leaves of Gnetum africanum (L.) and Gnetum bucholzianum (L.) (Gnetaceae) from Cameroon American Journal of Research Communication, 2(12): 101112.

Nkongho, G., Achidi, A., Ntonifor, N., Numfor, F., Dingha, B., Jackal, L. and Bonsi, C. (2014): Sweet potatoes in Cameroonnutritional profile of the leaves and their potential new use in local foods. African Journal of Agricultural Research, 9(8) 1371-1377.

Nwankwo, C., S., Ebenezer, I., A., Ikpeama, A., I. and Asuzu, F., O. (2014) : The nutritional and anti-nutritional values of two culinary herbs-uziza leaf (Piper guineense) and scent leaf (Ocimum gratissium) popularly used in Nigeria: International Journal of Science and Engineering Research 5(15):1160-1163 .

Oduro, I., Ellis, W.O., and Owusu, D.(2008) : Nutritional potential of two leafy vegetables: Moringa oleifera and Ipomoea batatas leaves. Scientific Research and Essay, 3(2), pp. 057-060.

Offor, I.,F., Ehiri, R.,C. and Njoku, C.,N.(2014): Proximate nutritional analysis and heavy metal composition of dried Moringa oleifera leaves from Oshirionich L.G.A, Ebonyi State Nigeria. Journal of Environmental Science, Toxicology and food technology (IOSR-JESTFT), 8(1), 57- 62.

Ogbe, A. O., and Affiku, J. P. (2011): Proximate study, mineral and anti-nutrient composition of Moringa oleifera leaves harvested from Lafia, Nigeria: potential benefits in poultry nutrition and health. The Journal of Microbiology, Biotechnology and Food Sciences, 1(3): 296

Ola, F., C., and Oboh, G. (2000): Food Value of Two Nigerian Edible Mushrooms (Termitomycetus Stratus and Termitomycetes Robustus): The Journal of Technoscience, 4: 1-3.

Ologhobo, A., D. and Fetuga, B.,L.(1983) : Investigation on the trypsin inhibitor, hemagglutinin, phytic and tannic acid contents of cowpea Vigna unguiculata. Food Chem .; 12 (4): 249-254.

Onu, P. N., and Aniebo, A. O. (2011): Influence of Moringa oleifera leaf meal on the performance and blood chemistry of starter broilers. International Journal of Food, Agriculture and Veterinary Science, 1(1): 38-44.

Orhuamen, E., O., Olorunmaiye, K.,S. and Adeyemi, C.,O.(2012) : Proximate analysis of fresh and dry leaves of Telfairia occidentalis (Hook.f.) and Talinum triangulare (Jacq.) Willd Croatian Journal of Food Technology, Biotechnology and Nutrition, 7(3-4), 188191.

Owusu, D., Ellis, W. O., and Oduro, I. (2008): Nutritional potential of two leafy vegetables: Moringa oleifera and Ipomoea batatas leaves. Journal of Scientific Research and Essay, 3(2) 057060.

Patel, M., and Naik, S. N. (2010): Flowers of Madhuca indica J.F. Gmel.: Present status and future perspectives. Indian Journal of Natural Products and Resources, 1(4):438443

Pravina, P., Sayaji, D., and Avinash, M. (2013): Calcium and its role in human body. International Journal of Research in Pharmaceutical and Biomedical Sciences, 4(2): 659-668.

Rahman, M. A., Mossa, J. S., Al-Said, M. S., and Al-Yahya, M. A. (2004): Medicinal plant 


\section{Aletan and Kwazo: Analysis of the Proximate Composition, Anti-Nutrients......}

diversity in the flora of Saudi Arabia 1: a report on seven plant families. Fito terapia, 75(2): 149-161

Saad, A. A. M., and Asalam, A. A. (2015): Culture of leaves and immature fruits of Maerua crassifolia in vitro. International Journal of Information Research and Review, 2(3): 496-498.

Sahrawat, K.,L., Kumar, G.,R. and Rao, J.,K.,(2002) : Evaluation of triacid and dry ashing procedures for detecting potassium, calcium, iron, zinc, magnesium and copper in plant materials: Communication of Soil Sciences and Plant, 33: 95-102.

Saidu, A.,N. and Jideobi, N.,G.(2009) :The proximate and elemental analysis of some leafy vegetables grown in Minna and Environs. Journal of Applied Sciences and Environmental Management, 13(4): 21 - 22.
The British Medical Journal group (BMJ) (2015): Reducing salt and increasing potassium will have major global health benefits. In: Monsivais ,P., Drewnowski, A., Rehm, C.D, Maillot, M., Mendoza,A., Monsivals The feasibility of meeting the WHO guidelines for sodium and potassium: a crossnational comparison study. BMJ Open 2015;5:e006625. oi:10.1136/bmjopen-2014- $\quad 006625$ http://bmjopen.bmj.com downloaded 17/2/2016.

Udousoro, I. and Ekanem, P. (2013): Assessment of proximate composition of twelve edible vegetables in Nigeria: International Journal of Modern Chemistry, 4(2): 79-89.

Ukam, N., U. (2008): The potentials of some lesser known vegetables. Nigerian Journal of Nutrition and Science, 29: 299-305. 